\title{
EFFECT OF SELECTED FACTORS ON THE SAFETY INTEGRITY LEVEL (SIL)
}

\section{WPLYW WYBRANYCH CZYNNIKÓW NA POZIOM NIENARUSZALNOŚCI BEZPIECZEŃSTWA (SIL)}

\author{
Młynarski Stanisław ${ }^{1}$, Pilch Robert ${ }^{2}$, Kaczor Grzegorz ${ }^{1}$, \\ Smolnik Maksymilian ${ }^{2}$, Szkoda Maciej ${ }^{1}$, Szybka Jan ${ }^{2}$ \\ ${ }^{1}$ Politechnika Krakowska, ${ }^{2}$ AGH Akademia Górniczo-Hutnicza \\ mlynarski_st@poczta.onet.pl,pilch@agh.edu.pl
}

\begin{abstract}
The presented paper concerns the functional safety problems of technical systems. The characteristics of safety assessment, described in IEC 61508 standard are an introduction to the problems associated with the methodology of the calculation of Safety Integrity Levels (SIL). The parameters obtained from reliability indicators, were calculated for the purpose of assessing the impact of repair time for the elements of a given system on the SIL. The calculated values of failure rate and the probability of dangerous failure show the sensitivity of the system at different time to repair values for various reliability-wise configurations. The indicators characterizing the safety level, calculated of the system with no repair time are the basis for demonstrating the influence of repair on the safety integrity level.
\end{abstract}

Keywords: safety, safety integrity levels (SIL), reliability-wise configuration, repair time

Streszczenie: Praca dotyczy problematyki bezpieczeństwa funkcjonalnego systemów technicznych. Przedstawiona charakterystyka obowiazujacej w zakresie oceny bezpieczeństwa normy IEC 61508 jest wprowadzeniem do problemów zwiazanych z metodyka wyliczeń poziomów nienaruszalności bezpieczeństwa SIL. Prezentowane $w$ pracy wyliczenia parametrów $i$ wskaźników niezawodności przeprowadzono dla potrzeb oceny wptywu czasu odnowy elementów systemu na poziom bezpieczeństwa SIL. Wyliczone wartości intensywności uszkodzeń oraz prawdopodobieństwa niebezpiecznego uszkodzenia, charakteryzuja wrażliwość systemu na różne czasy odnowy oraz dla różnych struktur niezawodnościowych systemu. Wskaźniki charakteryzujace poziom bezpieczeństwa wyliczone dla systemów bez odnowy stanowia podstawe dla wykazania wpływu odnowy systemu na poziom nienaruszalności bezpieczeństwa systemu SIL.

Stowa kluczowe: bezpieczeństwo, poziomy nienaruszalności SIL, struktura niezawodnościowa, czas odnowy. 
Effect of selected factors on the Safety Integrity Level (SIL)

Wplyw wybranych czynników na poziom nienaruszalności bezpieczeństwa (SIL)

\section{Wstęp}

Wzrastające znaczenie zapewnienia bezpieczeństwa eksploatacji systemów technicznych wymaga opracowania metod wykrywania zagrożeń oraz zapewnienia dużej niezawodności systemów monitorujących zagrożenia. Jednym z kierunków działań, mających na celu poprawę tej sytuacji było uchwalenie standardów dotyczących bezpieczeństwa $\mathrm{w}$ przemyśle. The International Society of Automation zaproponowała koncepcję poziomów nienaruszalności bezpieczeństwa. Natomiast Międzynarodowa Komisja Elektrotechniczna uchwaliła normę IEC 61508 Functional Safety of Electrical/Electronic/Programmable Electronic Safety-Related Systems, która została przygotowana w taki sposób, aby ułatwić ilościową ocenę bezpieczeństwa dla programowalnych systemów automatyki [1]. Rozważania nad oceną poziomu nienaruszalności bezpieczeństwa funkcjonalnego ujętego w normie IEC 61508 odnoszą się zasadniczo do systemów z odnową. Oznacza to, że uszkodzone elementy systemu są poddawane pełnej odnowie, a funkcje systemu są w pełni przywracane.

Zastosowanie systemów bezpieczeństwa może mieć miejsce we wszystkich możliwych warunkach eksploatacji. W związku z tym zapewnienie wysokiego poziomu nienaruszalności bezpieczeństwa funkcjonalnego $\mathrm{w}$ założonym czasie eksploatacji musi uwzględniać sytuacje uszkodzenia elementów systemu oraz czas jego odnowy. W zależności od składu oraz struktury systemu czas pozostawania elementów w stanie niezdatności może stać się kluczowym problemem bezpieczeństwa funkcjonalnego. Skuteczność procesu wykrywania zagrożenia i zachowanie bezpieczeństwa systemu jest funkcją niezawodności procesu wykrywania i bezpieczeństwa systemu. Niezawodność systemu zależy od struktury niezawodnościowej i jakości wykonania elementów. Wynika z tego, że nadrzędną rolę $\mathrm{w}$ procesie zachowania bezpieczeństwa zajmują zagadnienia dotyczące struktur niezawodnościowych tych systemów a następnie niezawodności elementów i czas odnowy systemu. Mając na uwadze powyższe stwierdzenia, $\mathrm{w}$ niniejszej pracy przeprowadzono ocenę poziomu nienaruszalności bezpieczeństwa SIL w zależności od czasu odnowy i struktury niezawodnościowej dla określonej niezawodności elementów systemu.

\section{Ocena bezpieczeństwa funkcjonalnego w świetle dotychczasowych opracowań}

Złożoność zagadnień dotyczących niezawodności i bezpieczeństwa funkcjonalnego systemów technicznych oraz wzrost ich znaczenia zaowocowały powstaniem licznych prac naukowych, poświęconych tej tematyce [2-8]. Przykładowo, autor pracy [11] przedstawił przegląd wybranych zagadnień związanych $\mathrm{z}$ analizą bezpieczeństwa funkcjonalnego, zgodnie z aktualnie obowiązującymi normami IEC 61508 oraz IEC 61511 [12]. Opisano znaczenie podejścia probabilistycznego do ilościowych analiz i weryfikacji poziomów SIL. W pracy [5] zaprezentowano ilościowy model probabilistyczny, który wykorzystuje poziomy nienaruszalności bezpieczeństwa (SIL) do oceny bezpieczeństwa wybranego systemu transportowego. 
Mtynarski Stanistaw, Pilch Robert, Kaczor Grzegorz, Smolnik Maksymilian, Szkoda Maciej, Szybka Jan

Do oceny bezpieczeństwa tego systemu zastosowano m.in. metodę symulacji Monte Carlo. W pracy [9] autorzy opisują kompleksowe ujęcie problemu bezpieczeństwa obiektów technicznych. W prowadzonych rozważaniach podają algorytmy i sposoby systemowych rozwiązań zapewnienia bezpieczeństwa eksploatacji obiektów technicznych. Autorzy pracy [10] prezentują wykorzystanie programów z zastosowaniem metod symulacyjnych do analizy bezpieczeństwa pojazdów. Międzynarodowe normy IEC 61508 oraz IEC 61511, które zawierają ogólne informacje dla projektowania i wdrażania systemów bezpieczeństwa funkcjonalnego, nie uwzględniają czynników ludzkich i organizacyjnych [3]. Autorzy pracy [13] przedstawili własną koncepcję oceny poziomów SIL, oraz udowodnili, że wzięcie pod uwagę wymienionych czynników może wpłynąć na zwiększenie bezpieczeństwa funkcjonalnego systemów technicznych.

\section{Podstawy oceny bezpieczeństwa według IEC 61508}

Norma IEC 61508 jest powszechne uznaną normą w dziedzinie bezpieczeństwa funkcjonalnego systemów programowalnych. Elektryczne, elektroniczne oraz programowalne urządzenia automatyki (E/E/PE) są odpowiedzialne za wykonywanie coraz większej ilości funkcji związanej $\mathrm{Z}$ zapewnieniem wymaganego poziomu bezpieczeństwa. Systemy bezpieczeństwa składające się z bardzo dużej liczby takich elementów posiadają zwykle złożone struktury niezawodnościowe jak: struktura progowa typu $\mathrm{k} \mathrm{z} \mathrm{n}$, czy z rezerwą przesuwającą się, co z praktycznego punktu widzenia komplikuje dokładne określenie rodzajów potencjalnych uszkodzeń oraz przeprowadzenie analizy w różnych warunkach eksploatacji [14]. Norma IEC 61508 zawiera szczegółowe wytyczne umożliwiające realizację i ocenę systemu związanego z bezpieczeństwem, który ma zredukować ryzyko uszkodzeń do minimalnego akceptowalnego poziomu zgodnie z zasadą ALARP (As Low As Reasonably Practicable). Istotnym czynnikiem dla systemu nadzorującego bezpieczeństwo jest zapewnienie, że będzie on zdolny do realizacji określonych funkcji użytkowych, wtedy kiedy jest to wymagane. Zwykle jest to wyrażane prawdopodobieństwem niezadziałania pętli dozorowej. Zgodnie z IEC 61508 obliczenia dla systemu związanego z bezpieczeństwem zależą od rodzaju pracy tego systemu [3]. Norma odnosi się zarówno do systemów bezpieczeństwa działających na żądanie, takich jak system awaryjnego wyłączenia oraz systemów pracujących w sposób ciągły takie jak system sterowania procesem:

- rodzaj pracy na rzadkie przywołanie - gdy system związany z bezpieczeństwem jest przywoływany nie częściej niż raz na rok i nie częściej niż wynosi dwukrotność testów okresowych,

- rodzaj pracy na częste przywołanie lub ciągłe przywołanie - gdy system związany z bezpieczeństwem jest przywoływany częściej niż raz na rok i częściej niż wynosi dwukrotność testów okresowych.

Norma IEC 61508 wymaga określenia celów dla przyrządowego systemu bezpieczeństwa (SIS). Cele niezawodnościowe powinny być przypisane do funkcji bezpieczeństwa związanej z SIS. 
Effect of selected factors on the Safety Integrity Level (SIL)

Wpływ wybranych czynników na poziom nienaruszalności bezpieczeństwa (SIL)

Dla pętli dozorowej pracującej $\mathrm{w}$ trybie na rzadkie przywołanie właściwym wskaźnikiem oceny bezpieczeństwa jest średnie prawdopodobieństwo uszkodzenia $P F D_{\text {avg. }}$ Dla systemów pracujących na przywołanie ciągłe należy posługiwać się prawdopodobieństwem niebezpiecznego uszkodzenia na godziną $P F H$.

Uproszczony schemat systemu bezpieczeństwa przedstawiono na rysunku 1, gdzie zgodnie z normą wyróżniono trzy podsystemy zapewniające realizację wybranej funkcji bezpieczeństwa:

- podsystem czujnikowy (PC) dostarczający informacji o wartościach określonych parametrów z obszaru, który objęty jest systemem bezpieczeństwa realizującym określone funkcje bezpieczeństwa,

- podsystem logiczny $(P L)$, który zgodnie z zaprogramowaną logiką wykonuje operacje logiczne na sygnałach $\mathrm{z}$ czujników $\mathrm{i}$ w ich wyniku generuje odpowiedni sygnał dla danej funkcji bezpieczeństwa przesyłając go do układów sterujących elementami wykonawczymi,

- podsystem wykonawczy (PW) realizujący $\mathrm{w}$ razie konieczności wymagane czynności dla danej funkcji bezpieczeństwa.

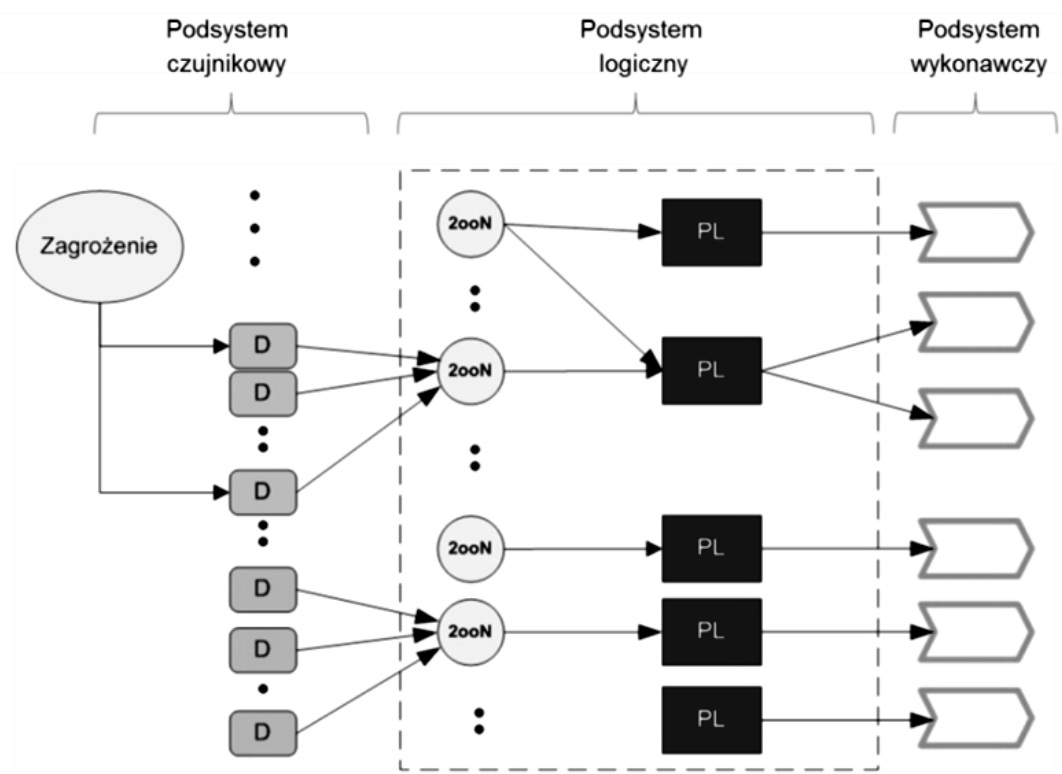

Rys. 1. Schemat systemu bezpieczeństwa

Wyznaczenie prawdopodobieństwa niebezpiecznego uszkodzenia na godzinę $\left(P F H_{i}\right)$ każdego $\mathrm{z}$ podsystemów i ich zsumowanie daje prawdopodobieństwo niebezpiecznego uszkodzenia na godzinę $\left(\mathrm{PFH}_{\mathrm{SYS}}\right)$ całego systemu realizującego daną funkcję bezpieczeństwa, zgodnie z poniższą zależnością:

$$
P F H_{S Y S}=P F H_{P C}+P F H_{P L}+P F H_{P W}
$$


Zgodnie z normą intensywność uszkodzeń systemu $\lambda$, określana w normie jako całkowita intensywność uszkodzeń systemu, może być wyrażona jako:

$$
\lambda=\lambda_{S}+\lambda_{D}
$$

gdzie:

$\lambda_{S}$ - intensywność uszkodzeń bezpiecznych,

$\lambda_{D}-$ intensywność uszkodzeń niebezpiecznych.

Wielkości te są dalej kategoryzowane na wykrywalne i niewykrywalne w celu odzwierciedlenia zdolności diagnostycznych systemu:

$$
\lambda_{S}=\lambda_{S D}+\lambda_{S U}
$$

oraz:

$$
\lambda_{D}=\lambda_{D D}+\lambda_{D U}
$$

gdzie:

$\lambda_{S D}$ - intensywność uszkodzeń bezpiecznych wykrywalnych;

$\lambda_{S U}-$ intensywność uszkodzeń bezpiecznych niewykrywalnych;

$\lambda_{D D}-$ intensywność uszkodzeń niebezpiecznych wykrywalnych;

$\lambda_{D U}-$ intensywność uszkodzeń niebezpiecznych niewykrywalnych.

W normie IEC 61508 zdefiniowano cztery poziomy nienaruszalności bezpieczeństwa SIL jako miary niezawodności systemu (tabela 1).

Tabela 1. Poziomy nienaruszalności bezpieczeństwa SIL wg IEC 61508 [1]

\begin{tabular}{|c|c|c|}
\hline $\begin{array}{c}\text { Poziom } \\
\text { nienaruszalności } \\
\text { bezpieczeństwa }\end{array}$ & $\begin{array}{c}\text { Prawdopodobieństwo } \\
\text { niebezpiecznego } \\
\text { uszkodzenia na } \\
\text { przywolanie rzadkie } \boldsymbol{P F D}\end{array}$ & $\begin{array}{c}\text { Prawdopodobieństwo } \\
\text { niebezpiecznego } \\
\text { uszkodzenia na } \\
\text { przywolanie ciągłe } \boldsymbol{P F H}\end{array}$ \\
\hline SIL 4 & od $10^{-5}$ do $10^{-4}$ & od $10^{-9}$ do $10^{-8}$ \\
\hline SIL 3 & od $10^{-4}$ do $10^{-3}$ & od $10^{-8}$ do $10^{-7}$ \\
\hline SIL 2 & od $10^{-3}$ do $10^{-2}$ & od $10^{-7}$ do $10^{-6}$ \\
\hline SIL 1 & od $10^{-2}$ do $10^{-1}$ & od $10^{-6}$ do $10^{-5}$ \\
\hline
\end{tabular}

Poziomy SIL są deklarowane ze względu na rodzaj zagrożenia, charakter pracy systemu oraz zadania wykonywane przez system.

\section{Obliczenia poziomu nienaruszalności bezpieczeństwa SIL dla wybranych struktur niezawodnościowych}

Obliczenia wskaźników potrzebnych do oceny poziomu nienaruszalności bezpieczeństwa SIL, wykonano z wykorzystaniem oprogramowania BlockSim. Metoda symulacji Monte Carlo, wykorzystywana przez pakiet oprogramowania firmy ReliaSoft polega na generowaniu losowych wartości czasu do uszkodzenia dla odpowiedniego rozkładu prawdopodobieństwa każdego z elementów systemu. 
Effect of selected factors on the Safety Integrity Level (SIL)

Wplyw wybranych czynników na poziom nienaruszalności bezpieczeństwa (SIL)

Niezawodność tego systemu jest wyznaczana w sposób empiryczny przez symulowanie realizacji jego złożonej pracy. Środowisko programowe BlockSim do tego celu wykorzystuje generator liczb losowych, oparty na algorytmie Ecuyer'a i losowaniu Baysa-Durhama. Korzystanie z metody symulacyjnej czasu poprawnej pracy $\mathrm{w}$ środowisku BlockSim wymaga wprowadzania wymaganych danych wejściowych. Należą do nich przede wszystkim czas trwania symulacji, wyrażony w przyjętych jednostkach wykonywanej pracy oraz ilość powtórzeń symulacji. Do realizacji obliczeń w niniejszej pracy przyjęto czas trwania symulacji równy 20000 godzin oraz 1000000 powtórzeń symulacji.

\section{Obliczenia dla struktur 1 z 1, 1 z 2, 2 z 3 oraz dla struktury 1 z 3}

Ocenę wpływu czasu odnowy na poziom nienaruszalności bezpieczeństwa SIL dokonano dla systemu o wymienionych powyżej strukturach niezawodnościowych. Obliczenia przeprowadzono zarówno bez uwzględnienia odnowy elementów systemu $(\mathrm{MTTR}=0)$ jak i dla wartości czasu odnowy wynoszących: $M T T R=8$ godz., 12 godz., 24 godz., 72 godz. oraz MTTR = 100 godz. Czas odnowy uwzględnia czas dojazdu, lokalizację, zasoby zapasów, zobowiązania serwisowe i ograniczenia środowiskowe.

Dla wszystkich analizowanych struktur, w ocenie nienaruszalności bezpieczeństwa przyjęto następujące założenia:

- liczba przywołań systemu bezpieczeństwa w ciągu roku może przekraczać 1, dlatego zastosowano metodę wyliczenia bazującą na przywołaniu ciągłym. W sytuacji takiej docelową miarą uszkodzeń systemu wg IEC 1508-4 jest prawdopodobieństwo niebezpiecznego uszkodzenia na godzinę $P F H$;

- producent sprzętu i oprogramowania systemu wymaga przeprowadzenia testów co 24 miesiące, stąd odstęp testu okresowego $T_{l}=17520$ godz.

W tabeli 2 zamieszczono dane niezawodnościowe elementów czujnikowych w analizowanym systemie. Pokrycie diagnostyczne $D C$ dla elementów systemu określa część uszkodzeń niebezpiecznych, które w teście diagnostycznym są wykrywalne. Parametr $\beta$ określa część niewykrytych uszkodzeń niebezpiecznych, które mają tzw. wspólną przyczynę. Wobec braku możliwości dokładnego określenia wartości tego parametru przyjęto, że będzie on stanowił całość tych uszkodzeń, które są niewykrywalne, czyli $(1-D C)$. Natomiast parametr $\beta_{D}$ określający tę część uszkodzeń o wspólnej przyczynie, które są wykrywalne - jak w EN 61508-6 - przyjęto na poziomie $0,5 \beta$.

Tabela 2. Dane niezawodnościowe elementów czujnikowych systemu

\begin{tabular}{|c|c|c|c|c|c|}
\hline Parametr & $\begin{array}{c}\boldsymbol{S F F} \\
{[\%]}\end{array}$ & $\begin{array}{c}\boldsymbol{\lambda}_{\boldsymbol{D}} \\
{[\mathbf{1} / \text { godz. }]}\end{array}$ & $\boldsymbol{\beta}$ & $\boldsymbol{\beta}_{\boldsymbol{D}}$ & $\begin{array}{c}\boldsymbol{D C} \\
{[\%]}\end{array}$ \\
\hline Wartość & $95,1 \%$ & $1,66 \times 10^{-6}$ & 0,08 & 0,04 & $93 \%$ \\
\hline
\end{tabular}


Oznaczenia z tabeli 2:

- SFF - udział uszkodzeń niebezpiecznych,

- $\lambda_{D}$ - intensywność uszkodzeń niebezpiecznych,

- $\beta$-określa część niewykrytych uszkodzeń niebezpiecznych, które mają wspólną przyczynę,

- $\beta_{D}$ - część uszkodzeń o wspólnej przyczynie, które są wykrywalne w teście diagnostycznym,

- $D_{C}$ - pokrycie diagnostyczne.

\section{Obliczenia SIL dla struktury 1 z 1}

$\mathrm{W}$ ramach prowadzonej analizy dla struktury $1 \mathrm{z} 1$, przedstawionej na rysunku 2, dokonano obliczeń intensywności uszkodzeń systemu $\lambda_{\text {sys }}$ oraz prawdopodobieństwa niebezpiecznego uszkodzenia $\mathrm{PFH}_{\text {sys }}$. Obliczenia dla różnych wartości czasu odnowy MTTR i odstępu testu okresowego $T_{1}=17520$ godz. zestawiono w tabeli 3 .

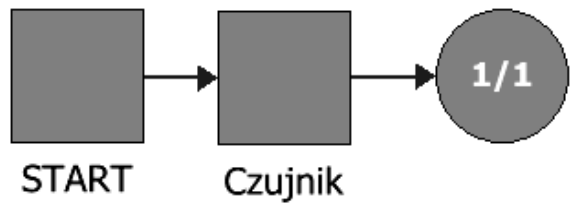

Rys. 2 Struktura 1 z 1

Tabela 3. Zestawienie wyników obliczeń dla struktury 1 z 1

\begin{tabular}{|l|c|c|c|}
\hline \multicolumn{1}{|c|}{ Przypadek } & $\begin{array}{c}\text { Intensywność } \\
\text { uszkodzeń } \\
\text { system } \lambda_{\text {sys }}\end{array}$ & $\begin{array}{c}\text { Prawdopodobieństwo } \\
\text { niebezpiecznego } \\
\text { uszkodzenia } \boldsymbol{P F H} \boldsymbol{H}_{\text {sys }}\end{array}$ & $\begin{array}{c}\text { Poziom } \\
\text { nienaruszalności } \\
\text { bezpieczeństwa } \\
\text { SIL }\end{array}$ \\
\hline $\begin{array}{l}\text { Bez uwzględnienia } \\
\text { czasu odnowy }\end{array}$ & $1,66 \times 10^{-6}$ & $5,81 \times 10^{-8}$ & SIL3 \\
\hline MTTR =8 godz. & $1,66 \times 10^{-6}$ & $5,81 \times 10^{-8}$ & SIL3 \\
\hline MTTR =12 godz. & $1,66 \times 10^{-6}$ & $5,81 \times 10^{-8}$ & SIL3 \\
\hline MTTR =24 godz. & $1,66 \times 10^{-6}$ & $5,81 \times 10^{-8}$ & SIL3 \\
\hline MTTR =72 godz. & $1,67 \times 10^{-6}$ & $5,85 \times 10^{-8}$ & SIL3 \\
\hline MTTR =100 godz. & $1,67 \times 10^{-6}$ & $5,85 \times 10^{-8}$ & SIL3 \\
\hline
\end{tabular}

$\mathrm{Na}$ rysunku 3 przedstawiono wartości intensywności uszkodzeń systemu $\lambda_{\text {sys }}$ $\mathrm{w}$ funkcji czasu odnowy dla struktury $1 \mathrm{z} 1$. Dla wszystkich analizowanych przypadków zaobserwowano stałą intensywność uszkodzeń na poziomie $1,66 \times 10^{-6}$ [1/godz.]. 
Effect of selected factors on the Safety Integrity Level (SIL)

Wplyw wybranych czynników na poziom nienaruszalności bezpieczeństwa (SIL)

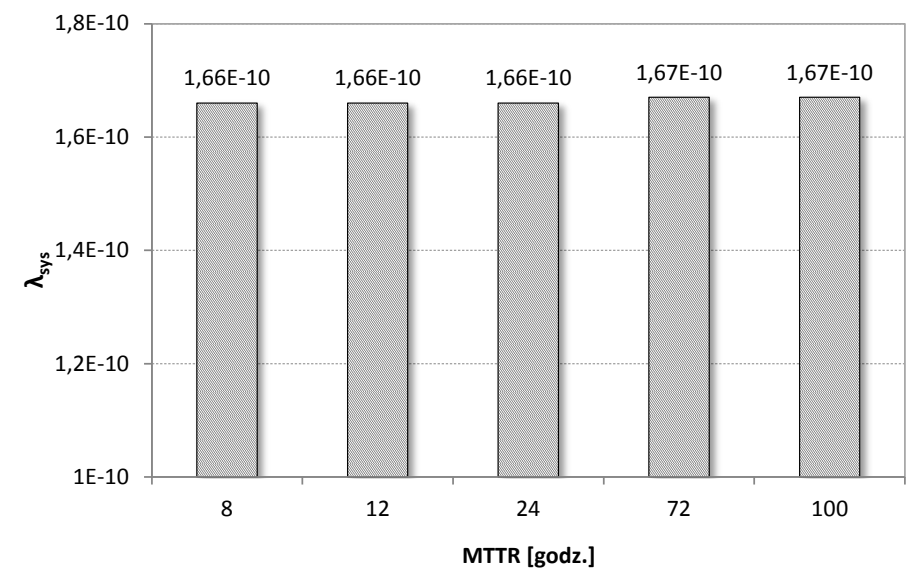

Rys. 3 Intensywność uszkodzeń systemu w funkcji czasu odnowy dla struktury 1z1

Obliczenia SIL dla struktury 1 z 2

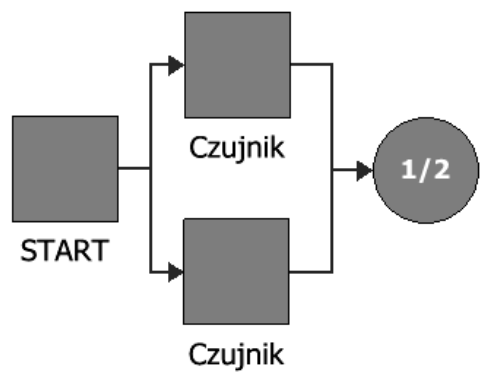

Rys. 4 Struktura 1 z 2

Tabela 4. Zestawienie wyników obliczeń dla struktury 1 z 2

\begin{tabular}{|l|c|c|c|}
\hline \multicolumn{1}{|c|}{ Przypadek } & $\begin{array}{c}\text { Intensywność } \\
\text { uszkodzeń } \\
\text { system } \lambda_{\text {sys }}\end{array}$ & $\begin{array}{c}\text { Prawdopodobieństwo } \\
\text { niebezpiecznego } \\
\text { uszkodzenia } \text { PFH }_{\text {sys }}\end{array}$ & $\begin{array}{c}\text { Poziom } \\
\text { nienaruszalności } \\
\text { bezpieczeństwa } \\
\text { SIL }\end{array}$ \\
\hline $\begin{array}{l}\text { Bez uwzględnienia } \\
\text { czasu odnowy }\end{array}$ & $9,25 \times 10^{-8}$ & $3,24 \times 10^{-9}$ & SIL4 \\
\hline MTTR =8 godz. & $5,70 \times 10^{-11}$ & $2,00 \times 10^{-12}$ & SIL4 \\
\hline MTTR =12 godz. & $7,80 v 10^{-11}$ & $2,73 \times 10^{-12}$ & SIL4 \\
\hline MTTR =24 godz. & $9,95 \times 10^{-11}$ & $3,48 \times 10^{-12}$ & SIL4 \\
\hline MTTR =72 godz. & $2,83 \times 10^{-10}$ & $9,90 \times 10^{-12}$ & SIL4 \\
\hline MTTR =100 godz. & $4,57 \times 10^{-10}$ & $1,60 \times 10^{-11}$ & SIL4 \\
\hline
\end{tabular}


Mtynarski Stanistaw, Pilch Robert, Kaczor Grzegorz, Smolnik Maksymilian, Szkoda Maciej, Szybka Jan

$\mathrm{Na}$ rysunku 5 przedstawiono wartości intensywności uszkodzeń systemu $\lambda_{\text {sys }}$ w funkcji czasu odnowy dla struktury $1 \mathrm{z} 2$. Wraz ze wzrostem czasu trwania

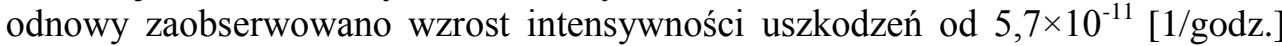
dla MTTR=8 godzin do 4,57×10 $0^{-10}$ dla MTTR=100 godzin.

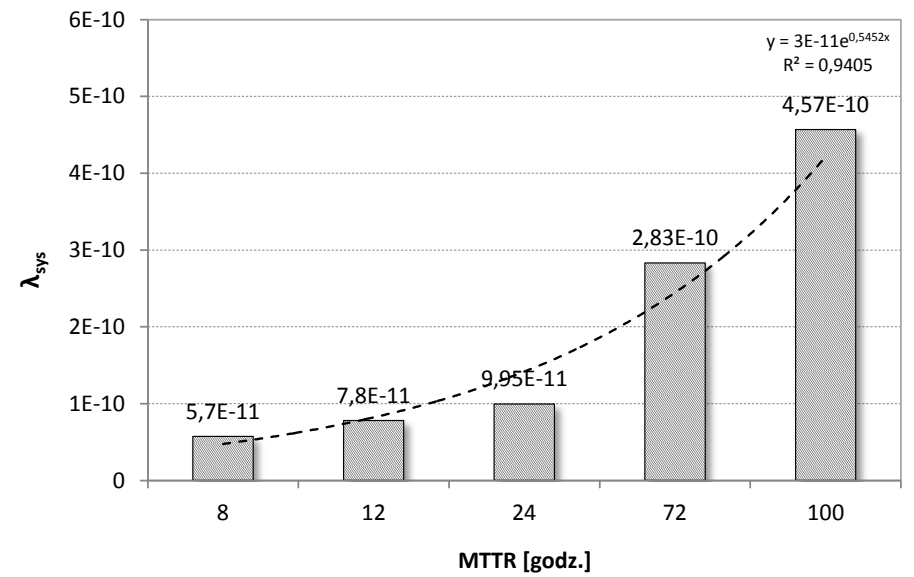

Rys. 5 Intensywność uszkodzeń systemu w funkcji czasu odnowy dla struktury 1 z 2

Obliczenia SIL dla struktury 2 z 3

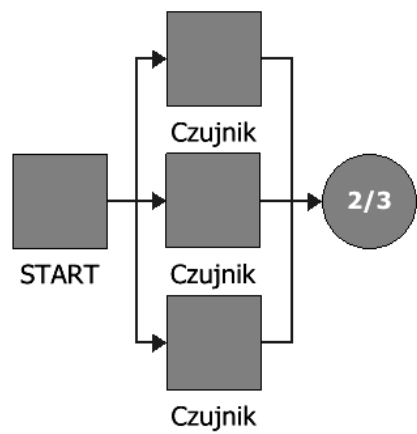

Rys.6 Struktura 2 z 3

Tabela 5. Zestawienie wyników obliczeń dla struktury 2 z 3

\begin{tabular}{|l|c|c|c|}
\hline \multicolumn{1}{|c|}{ Przypadek } & $\begin{array}{c}\text { Intensywnośćc| } \\
\text { uszkodzeń } \\
\text { system } \boldsymbol{\lambda}_{\text {svs }}\end{array}$ & $\begin{array}{c}\text { Prawdopodobieństwo } \\
\text { niebezpiecznego } \\
\text { uszkodzenia } \boldsymbol{P F H} \boldsymbol{H}_{\text {svs }}\end{array}$ & $\begin{array}{c}\text { Poziom } \\
\text { nienaruszalności } \\
\text { bezpieczeństwa SIL }\end{array}$ \\
\hline $\begin{array}{c}\text { Bez uwzględnienia } \\
\text { czasu odnowy }\end{array}$ & $2,70 \times 10^{-7}$ & $9,45 \times 10^{-9}$ & SIL4 \\
\hline MTTR =8 godz. & $1,14 \times 10^{-10}$ & $3,99 \times 10^{-12}$ & SIL4 \\
\hline MTTR $=12$ godz. & $1,71 \times 10^{-10}$ & $5,99 \times 10^{-12}$ & SIL4 \\
\hline MTTR $=24$ godz. & $2,85 \times 10^{-10}$ & $9,97 \times 10^{-12}$ & SIL4 \\
\hline MTTR $=72$ godz. & $8,65 \times 10^{-10}$ & $3,03 \times 10^{-11}$ & SIL4 \\
\hline MTTR $=100$ godz. & $1,48 \times 10^{-9}$ & $5,18 \times 10^{-11}$ & SIL4 \\
\hline
\end{tabular}


Effect of selected factors on the Safety Integrity Level (SIL)

Wplyw wybranych czynników na poziom nienaruszalności bezpieczeństwa (SIL)

$\mathrm{Na}$ rysunku 7 przedstawiono wartości intensywności uszkodzeń systemu $\lambda_{\text {sys }}$ w funkcji czasu odnowy dla struktury 2 z 3. Wraz ze wzrostem czasu trwania odnowy zaobserwowano wzrost intensywności uszkodzeń od $1,14 \times 10^{-10}$ [1/godz.] dla MTTR=8 godzin do $1,48 \times 10^{-9}$ dla MTTR=100 godzin.

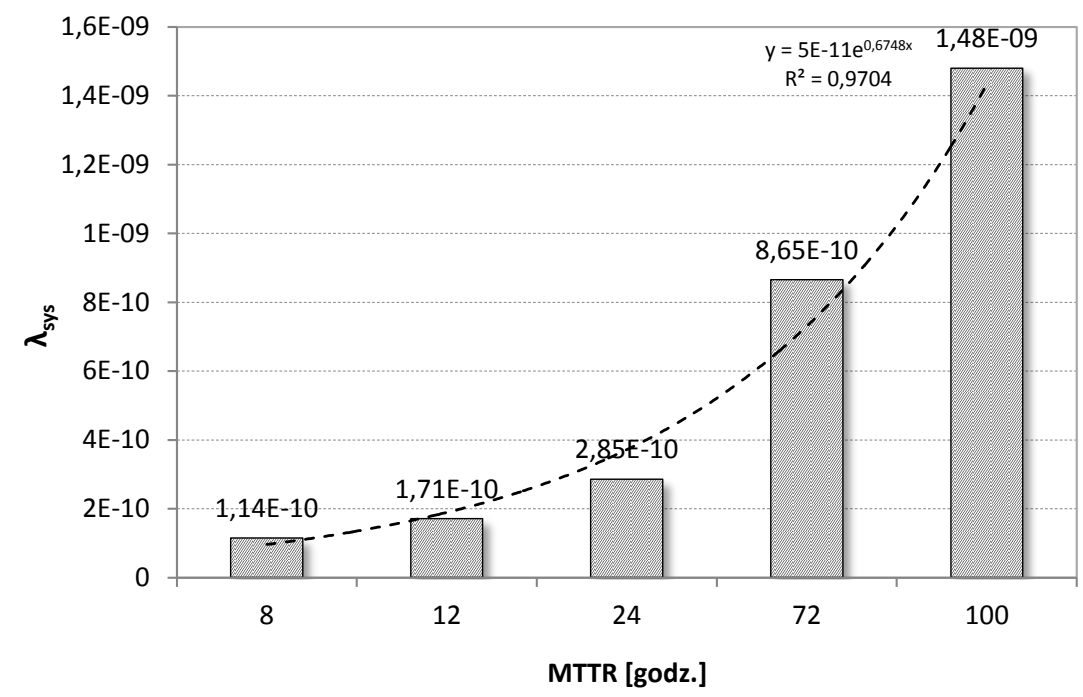

Rys. 7 Intensywność uszkodzeń systemu w funkcji czasu odnowy dla struktury 2 z 3

Przeprowadzono również obliczenia SIL dla struktury 4 z 6, a uzyskane wyniki zilustrowano na histogramie (rys. 8)

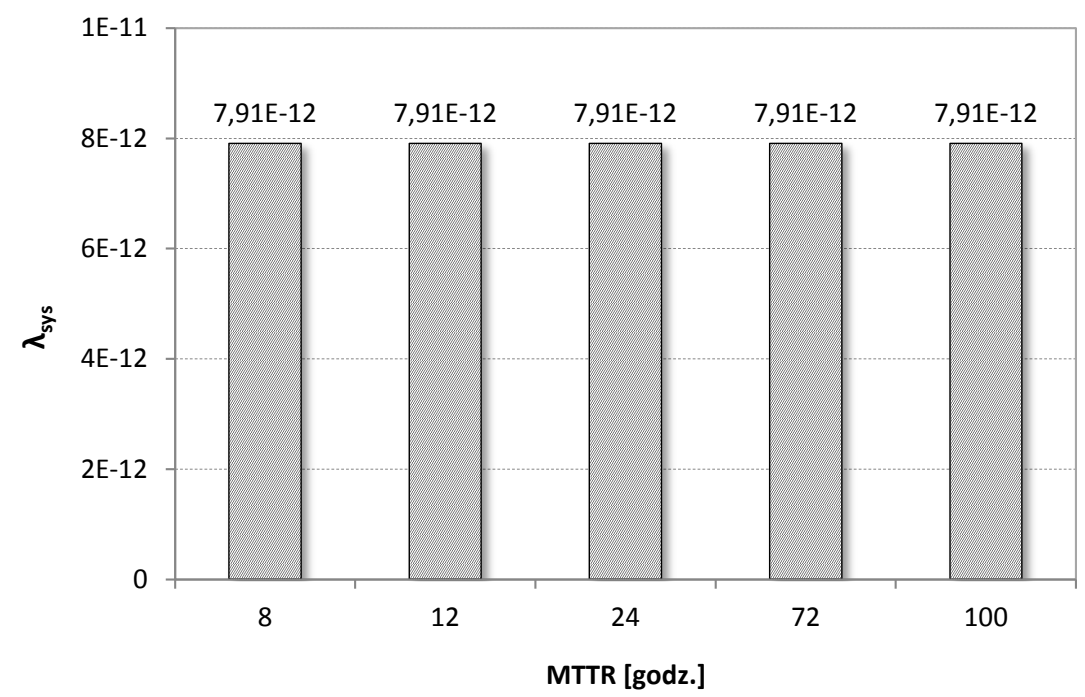

Rys. 8 Intensywność uszkodzeń systemu w funkcji czasu odnowy 
Mtynarski Stanistaw, Pilch Robert, Kaczor Grzegorz, Smolnik Maksymilian, Szkoda Maciej, Szybka Jan

Obliczenia SIL dla struktur 1 z 2 oraz 2 z 3 wg schematów blokowych niezawodności

\section{Obliczenia SIL dla struktury 1 z 2}

Otrzymane wyniki dla struktury 1 z 2 z uwzględnieniem czasu odnowy porównano z wynikami metody obliczeniowej wg schematów blokowych niezawodności opisanej w normie EN 61508-6. Do wyznaczenia prawdopodobieństwa uszkodzenia funkcji bezpieczeństwa systemu zastosowano zależności zdefiniowane w normie, a mianowicie:

$$
P F H_{G}=2 \cdot\left(\left(1-\beta_{D}\right) \cdot \lambda_{D}+(1-\beta) \cdot \lambda_{D U}\right)^{2} \cdot t_{C E}+\beta_{D} \cdot \lambda_{D D}+\beta \cdot \lambda_{D U}
$$

gdzie:

$\mathrm{PFH}_{G}$ - intensywność uszkodzeń bezpiecznych wykrywalnych;

$\beta_{D} \quad-$ część uszkodzeń o wspólnej przyczynie, które są wykrywalne w teście diagnostycznym,

$\beta \quad-$ określa część niewykrytych uszkodzeń niebezpiecznych, które mają wspólną przyczynę,

$\lambda_{D D} \quad-$ intensywność uszkodzeń niebezpiecznych wykrywalnych,

$\lambda_{D U} \quad-$ intensywność uszkodzeń niebezpiecznych niewykrywalnych,

$t_{c e} \quad-$ średni czas przestoju dla wyposażenia kanału struktury $1 \mathrm{z} 2$ :

$$
t_{C E}=\frac{\lambda_{D U}}{\lambda_{D}} \cdot\left(\frac{T_{1}}{2}+M T T R\right)+\frac{\lambda_{D D}}{\lambda_{D}} \cdot M T T R
$$

gdzie:

$\lambda_{D} \quad-$ intensywność uszkodzeń niebezpiecznych,

$T_{l} \quad$ - odstęp testu okresowego,

MTTR - średni czas odnowy.

Schemat blokowy dla struktury 1 z 2 systemu przedstawiono na rysunku 9.

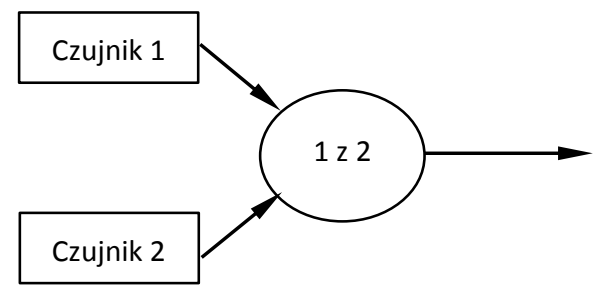

Rys. 9 Schemat blokowy dla struktury 1 z 2

Przykładowo, dla czasu odnowy $M T T R=24$ godz. oraz parametrów niezawodnościowych $\mathrm{z}$ tabeli 5, prawdopodobieństwo uszkodzenia funkcji bezpieczeństwa systemu wynosi:

$$
\begin{aligned}
& \mathrm{PFH}_{G}=2 \cdot\left((1-0,04) \cdot 1,54 \cdot 10^{-6}+(1-0,08) \cdot 1,16 \cdot 10^{-7}\right)^{2} \\
& \cdot 637,2+0,04 \cdot 1,54 \cdot 10^{-6}+0,08 \cdot 1,16 \cdot 10^{-7}=7,43 \cdot 10^{-8}-\text { poziom SIL3 }
\end{aligned}
$$


Effect of selected factors on the Safety Integrity Level (SIL)

Wpływ wybranych czynników na poziom nienaruszalności bezpieczeństwa (SIL)

Obliczenia dla innych wartości czasu odnowy zestawiono w tabeli 6 .

Tabela 6. Zestawienie wyników wg metody schematów blokowych niezawodności

\begin{tabular}{|l|c|c|}
\hline \multicolumn{1}{|c|}{ Przypadek } & $\begin{array}{c}\text { Prawdopodobieństwo } \\
\text { niebezpiecznego } \\
\text { uszkodzenia } \boldsymbol{P F H _ { \text { sys } }}\end{array}$ & $\begin{array}{c}\text { Poziom nienaruszalności } \\
\text { bezpieczeństwa SIL }\end{array}$ \\
\hline MTTR $=8$ godz. & $7,42 \times 10^{-8}$ & SIL3 \\
\hline MTTR $=12$ godz. & $7,42 \times 10^{-8}$ & SIL3 \\
\hline MTTR $=24$ godz. & $7,43 \times 10^{-8}$ & SIL3 \\
\hline MTTR $=72$ godz. & $7,45 \times 10^{-8}$ & SIL3 \\
\hline MTTR $=100$ godz. & $7,46 \times 10^{-8}$ & SIL3 \\
\hline
\end{tabular}

\section{Obliczenia SIL dla struktury 2 z 3}

Otrzymane wyniki dla struktury 2 z 3 z uwzględnieniem czasu odnowy porównano z wynikami metody obliczeniowej wg schematów blokowych niezawodności opisanej w normie EN 61508-6. Do wyznaczenia prawdopodobieństwa uszkodzenia funkcji bezpieczeństwa systemu zastosowano zależności zdefiniowane w normie:

$$
P F H_{G}=6 \cdot\left(\left(1-\beta_{D}\right) \cdot \lambda_{D D}+(1-\beta) \cdot \lambda_{D U}\right)^{2} \cdot t_{C E}+\beta_{D} \cdot \lambda_{D D}+\beta \cdot \lambda_{D U}
$$

gdzie:

$P_{F} H_{G}$ - intensywność uszkodzeń bezpiecznych wykrywalnych; pozostałe oznaczenia j.w.

Schemat blokowy dla struktury 2 z 3 systemu przedstawiono na rysunku 10 .

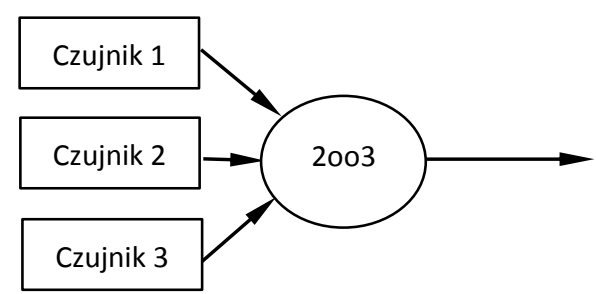

Rys. 10 Schemat blokowy dla struktury 2 z 3

Przykładowo, dla czasu odnowy $\mathrm{MTTR}=24$ godz. oraz parametrów niezawodnościowych $\mathrm{z}$ tabeli 2 , prawdopodobieństwo uszkodzenia funkcji bezpieczeństwa systemu wynosi:

$$
\begin{aligned}
& \text { PFH }_{G}=6 \cdot\left((1-0,04) \cdot 1,54 \cdot 10^{-6}+(1-0,08) \cdot 1,16 \cdot 10^{-7}\right)^{2} \\
& \cdot 637,2+0,04 \cdot 1,54 \cdot 10^{-6}+0,08 \cdot 1,16 \cdot 10^{-7}=8,07 \cdot 10^{-8}-\text { poziom SIL3 }
\end{aligned}
$$

Obliczenia dla innych wartości czasu odnowy zestawiono w tabeli 7. 
Mtynarski Stanistaw, Pilch Robert, Kaczor Grzegorz, Smolnik Maksymilian, Szkoda Maciej, Szybka Jan

Tabela 7. Zestawienie wyników obliczeń dla struktury 2 z 3

\begin{tabular}{|l|c|c|}
\hline \multicolumn{1}{|c|}{ Przypadek } & $\begin{array}{c}\text { Prawdopodobieństwo } \\
\text { niebezpiecznego } \\
\text { uszkodzenia } \boldsymbol{P F H}_{\text {sys }}\end{array}$ & $\begin{array}{c}\text { Poziom nienaruszalności } \\
\text { bezpieczeństwa SIL }\end{array}$ \\
\hline MTTR $=8$ godz. & $8,05 \times 10^{-8}$ & SIL3 \\
\hline MTTR $=12$ godz. & $8,05 \times 10^{-8}$ & SIL3 \\
\hline MTTR =24 godz. & $8,07 \times 10^{-8}$ & SIL3 \\
\hline MTTR =72 godz. & $8,14 \times 10^{-8}$ & SIL3 \\
\hline MTTR =100 godz. & $8,19 \times 10^{-8}$ & SIL3 \\
\hline
\end{tabular}

\section{Podsumowanie}

Przedstawione wyniki obliczeń świadczą, że w zapewnieniu bezpieczeństwa istotne znaczenie mają struktury niezawodnościowe systemu.

Analizując wpływ czasu odnowy elementów na bezpieczeństwo systemu uzyskano wyniki, które świadczą, że istnieje zróżnicowanie w prawdopodobieństwie niebezpiecznego uszkodzenia na godzinę $P F H_{s y s}$. W zależności od czasu przeprowadzania odnowy oraz od struktury niezawodnościowej systemu. Duże różnice występowały $\mathrm{w}$ wartościach wskaźników dotyczących bezpieczeństwa systemów z odnową oraz bez odnowy elementów systemu, natomiast wydłużanie czasu odnowy nie zawsze wpływa w taki sam sposób. Czynnikiem, od którego wyraźnie zależy bezpieczeństwo systemu w funkcji czasu odnowy jest występująca liczba elementów w strukturze równoległej. Obliczenia niezawodności tylko dla struktury 1 z 1 oraz 4 z 6 wykazały bardzo małą, niezauważalną wrażliwość nawet na przyjmowanie bardzo długiego czasu odnowy systemu. Te wyniki świadczą, że długość czasu odnowy w porównaniu do przyjętego sposobu kontroli stanu elementów i dużej redundancji w strukturze systemu ma niewielki wpływ na jego niezawodność.

W pozostałych dwóch badanych przypadkach struktur 1 z 2 oraz 2 z 3 wzrost intensywności uszkodzeń następował proporcjonalnie $\mathrm{z}$ wydłużaniem się czasu odnowy. Występujące zmiany wartości intensywności uszkodzeń dla czasu odnowy MTTR w zakresie od 8 godz. do 100 godz. kształtowały się w wielkościach nieprzekraczających jednego poziomu SIL. W drugim artykule zgłoszonym przez autorów w ramach Zimowej Szkoły Niezawodności 2015 wyniki uzyskane dla wybranych struktur wg normy EN 61508 porównano z obliczeniami wykonanymi przy założeniu, że proces uszkodzeń i odnów jest procesem Markowa.

\section{Literatura}

[1] IEC 61508 Functional safety of electrical/electronic/programmable electronic safety-related systems.

[2] Szkoda M.: Assessment of Reliability, Availability and Maintainability of Rail Gauge Change Systems, Eksploatacja i Niezawodnosc - Maintenance and Reliability 2014; 16 (3) 422-432. 
Effect of selected factors on the Safety Integrity Level (SIL)

Wplyw wybranych czynników na poziom nienaruszalności bezpieczeństwa (SIL)

[3] Beugin J., Renaux L., Cauffriez L.: A SIL quantification approach based on an operating situation model for safety evaluation in complex guided transportation systems, Reliability Engineering and System Safety 2007; 92: 1686-1700.

[4] Guo H., Yang X. A simple reliability block diagram method for safety integrity verification. Reliability Engineering and System Safety 2007; 92: 1267-1273.

[5] Manzini R., Regattieri A. Pham H. Ferrari E.: Maintenance for Industrial Systems, Springer-Verlag Gmbh, 2010.

[6] Langeron Y. Barros A. Grall A. Bérenguer C.: Combination of safety integrity levels (SILs): A study of IEC61508 merging rules, Journal of Loss Prevention in the Process Industries, 2008; 21, 437-449.

[7] Edward M., Marszal P.E.: Derivation of an equation for quantitative SIL assignment, ISA Transaction, 2003; 42, 163-165.

[8] Młynarski S., Oprzędkiewicz J.: Systemowe rozwiązania zapewnienia bezpieczeństwa i niezawodności obiektów technicznych, Problemy Eksploatacji, Maintenance Problems, 3/2012, 39-54.

[9] Młynarski S., Pałka E.: Symulacyjna metoda analizy bezpieczeństwa pojazdu szynowego, Pojazdy Szynowe, 2/2011, 39-42.

[10] Kosmowski K. T.: Functional safety concept for hazardous systems and new challenges, Journal of Loss Prevention in the Process Industries, 2006: 19, 298-305.

[11] IEC 61511 Functional safety - Safety instrumented systems for the process industry.

[12] Schönbeck M. Rausand M. Rouvroye J.: Human and organizational factors in the operational phase of instrumented systems: A new approach, Safety Science 2013: 48, 310-318.

[13] Szkoda M.: Wskaźniki niezawodności środków transportu szynowego, Logistyka, 3/2012, 2195-2201.

[14] Szybka J.: Methodology for reliability estimation of systems with sliding reserve, Scientific Problems of Machines Operation and Maintenance 3 (163) 2010, 65-73.

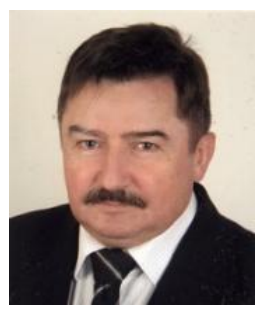

Dr inz. Stanislaw Młynarski ukończyt studia na Wydziale Mechanicznym Politechniki Krakowskiej. Odbyt 2 letni staż zawodowy w NY USA w Zakładach Mechaniki Precyzyjnej. Ukończyt studia doktoranckie na Wydziale Mechanicznym PK i uzyskat stopień doktora nauk technicznych. Obecnie pracownik naukowo-dydaktyczny Politechniki Krakowskiej na stanowisku adiunkta. Specjalizuje się $w$ dziedzinie eksploatacji, niezawodności oraz bezpieczeństwa maszyn, pojazdów i systemów technicznych. 